\title{
NEW SPECIES AND RECORDS OF CHAROPS HOLMGREN, 1859 (HYMENOPTERA: ICHNEUMONIDAE: CAMPOPLEGINAE)
}

\author{
ZOLTÁN VAS \\ Hymenoptera Collection, Department of Zoology, Hungarian Natural History Museum \\ H-1088 Budapest, Baross u. 13, Hungary \\ E-mail:vas.zoltan@nhmus.hu, https://orcid.org/0000-0002-1361-180X
}

\begin{abstract}
New species and new records of Charops Holmgren, 1859 (Ichneumonidae: Campopleginae) are reported from the Oriental, Neotropical, Palaearctic and Afrotropical regions. Three new species are described: Charops aeruginosus sp. n. from Taiwan, Charops electrinus sp. n. from Uganda and Charops juliannae sp. n. from Tanzania. The Afrotropical fauna of the genus is overviewed and an identification key is provided. The first records of Charops armatus Seyrig, 1935 from Ethiopia, Charops diversipes Roman, 1910 from Uganda, Charops lucianae Santos et Onody, 2019 from Argentina, and Charops cantator (DeGeer, 1778) from Syria are given.
\end{abstract}

Key words: new species, Charops, Hymenoptera, Ichneumonidae, Campopleginae, Afrotropical, Neotropical, Oriental, Palaearctic.

\section{INTRODUCTION}

Charops Holmgren, 1859 is a moderately species-rich genus of Campopleginae, a diverse and economically important subfamily of ichneumon wasps (or recently also called as Darwin wasps) (Hymenoptera: Ichneumonidae). Prior to this study 35 valid species were known worldwide; 12 species have been listed to occur in the Oriental region, 11 in the Afrotropical, 9 in the Neotropical, 5 in the Eastern Palaearctic, 2 in the Western Palaearctic, 2 in the Australasian, and 1 in the Nearctic regions (Yu \& Horstmann 1997, Yu et al. 2012, SAntos et al. 2019). The genus is more diverse in tropical and subtropical zones than in the regions with a temperate climate, and its species are koinobiont parasitoids of various lepidopterous hosts (GUPTA \& MAHESHWARY 1971). Charops could be easily distinguished from the most similar Oriental and Eastern Palaearctic genus Scenocharops Uchida, 1932, as fore wing lacks areolet and second recurrent vein $(2 m-c u)$ is vertical in Charops, while fore wing usually has areolet and second recurrent vein $(2 m-c u)$ is inclivous in Scenocharops (Townes 1970a, Gupta \& Maheshwary 1977). Most Charops species were described more than hundred years or several decades ago, and, since the publication of the Ichneumonidae world catalogue (Yu \& Horstmann 1997), one Western Palaearctic species (Horstmann 2008) and seven Neotropical species (SAnTos et al. 2019) were described. 
In this paper, based on the material of the Hymenoptera Collection of the Hungarian Natural History Museum (HNHM, Budapest), three new species of the genus are described (two from Afrotropics and one from Orientalis). The Afrotropical Charops fauna is overviewed with an identification key provided, and new records and corrections of distributional data of several species are given.

\section{MATERIAL AND METHODS}

Taxonomy and nomenclature follow Yu and Horstmann (1997), Yu et al. (2012), and Kittel (2016); hence, complete nomenclatural history and list of synonym taxa are not repeated here. The morphological terminology is primarily based on GAULD (1991) and GAUld et al. (1997); however, in some cases, the corresponding terminology of Townes (1969) is also indicated. Sculpture terminology is based on HARris (1979). The identifications were based on Brullé (1846), Cresson (1865), Magretti (1884), Ashmead (1890), Cameron (1905, 1906), Szépligeti $(1906,1908,1910)$, Roman (1910), Girault (1925), Seyrig (1935), Townes et al. (1961), Townes $(1970 a, b)$, Gupta and Maheshwary (1971), Maheshwary (1971), Townes and Townes (1973), Gupta and Maheshwary (1977), He et al. (1996), Jonathan (1999), Choi and Lee (2008), Horstmann (2008), van Noort (2019), Santos et al. (2019), and on checking the relevant type material (type specimens of all species listed in the Taxonomy and Biogeography section were examined at least by photos except those of Charops cantator (DeGeer, 1778) and Charops flavipes Brullé, 1846; the former was unnecessary to check, the latter is lost). The specimens were identified and examined by the author using a Nikon SMZ645 stereoscopic microscope. Results are grouped into biogeographical regions. Within biogeographical regions, species are listed alphabetically. All mentioned specimens are deposited in the Hymenoptera Collection of the HNHM. Photos were taken with Nikon D5200 and Nikon AF Micro Nikkor $60 \mathrm{~mm}$ lens and MitutoyoM Plan Apo 5X microscope lens and with $14 \mathrm{MP}$ MicroQ-U3L digital camera. Post image work was done with ToupTek ToupView v4.7 and Photoshop CS5.

\section{TAXONOMY AND BIOGEOGRAPHY}

Subfamily: Campopleginae Förster, 1869

Genus: Charops Holmgren, 1859

Type species: Campoplex decipiens Gravenhorst, 1829; monobasic.

Diagnosis: Head lenticular; gena (temple) very short, very strongly narrowed behind eye; inner margin of eye strongly indented; occipital carina complete, reaching hypostomal carina at base of mandible; areolet absent; second recurrent vein $(2 \mathrm{~m}-\mathrm{cu})$ vertical, lower external angle of second discal cell about right-angled; propodeal carinae at least partly reduced; suture separating first tergite from first sternite situated strongly above mid-height at basal third of first metasomal segment, at extreme basal part reaches its upper edge, suture always present; ovipositor sheath always less than twice as long as apical depth of metasoma. 


\section{Oriental region}

\section{Charops aeruginosus sp. $n$.}

(Figs 1-3)

Type material - Holotype: female, Formosa [= Taiwan], Kosempo [= Jiasianpu hill near Jiasian], IV.[1]908, leg. [H.] Sauter; specimen pinned, Id. No. HNHM-HYM 153211. - Paratype: female, Formosa [= Taiwan], Teraso [= Manchoutsun], II.1909, leg. [H.] Sauter; specimen pinned, Id. No. HNHM-HYM 153212. - The holotype and paratype specimens are deposited in the Hymenoptera Collection of HNHM (Budapest, Hungary).

Diagnosis - Charops aeruginosus sp. n. could be easily identified by the combination of the following characters: tegula light brownish, fore and middle femora entirely orange, hind femur predominantly rusty reddish, hind tibia brown, metasoma predominantly ferruginous with black to dark brown patches, wings weakly infuscate, indistinct propodeal carination, coarsely and entirely reticulate-rugose mesopleuron with transverse wrinkles along posterior margin, and large size.

Description - Female (Figs 1-3). Body length ca. $14 \mathrm{~mm}$, fore wing length ca. $7.5 \mathrm{~mm}$.

Head: Antenna with 45-46 flagellomeres; first flagellomere ca. 2.5-2.7× as long as apically wide; preapical flagellomeres quadrate to slightly longer than wide. Head lenticular, matt, its anterior surface rather coarsely rugose, posterior surface granulate with indistinct punctures, and with dense, long, greyish hairs. Ocular-ocellar distance $0.4 \times$ as long as ocellus diameter, posterior ocellar distance about as long as ocellus diameter. Inner eye orbits strongly indented and weakly convergent ventrally. Malar space ca. $0.4 \times$ as long as basal width of mandible. Face flat in profile, narrowed ventrally, minimal width of face ca. $0.65-0.7 \times$ as long as eye length. Clypeus very weakly separated from face, convex in profile, its apical margin convex, sharp. Mandible short, high, lower margin of mandible with rather wide flange from teeth toward base, flange abruptly narrowed at teeth, mandibular teeth of equal length.

Mesosoma: Mesosoma with dense, moderately long, greyish hairs. Pronotum smooth with strong transverse wrinkles, its upper edge and posterior corner rugose; epomia strong. Mesoscutum coarsely rugose, weakly convex in profile, little shorter than wide, notaulus not developed. Scuto-scutellar groove very narrow. Scutellum coarsely rugose, wide, flat, medially widely impressed, concave, lateral carina indistinct. Mesopleuron very strongly sculptured, coarsely reticulate-rugose with transverse wrinkles along posterior margin; mesopleural suture not impressed. Epicnemial carina complete, strong, pleural part bent to anterior margin of mesopleuron reaching it above its middle height, transversal part (i.e. part at the level of sternaulus running through the epicnemium to the ventral edge of pronotum) developed, ventral part (behind fore coxae) complete, not elevated. Sternaulus indistinct. Posterior transverse carina of mesosternum complete, medially slightly excised, submedially developed into a pair of tooth-like, triangular processes. Metanotum coarsely rugose, short, about $0.3 \times$ as long as scutellum. Metapleuron coarsely rugose; juxtacoxal carinae distinct, strong; submetapleural carina complete, strong. Pleural carina of propodeum strong; propodeal spiracle rather strongly elongate, narrow, separated from pleural 
carina by about $0.5 \times$ its length, connected to pleural carina by a distinct ridge. Propodeum rather coarsely rugose with irregular wrinkles, long, its apex reaching beyond middle length of hind coxa, propodeal carinae indistinct. Fore wing without areolet, 3rs- $m$ missing; pterostigma long and narrow; second recurrent vein $(2 m-c u)$ distal to intercubitus $(2 r s-m)$ by about $0.5-0.7 \times$ length of intercubitus; distal abscissa of $R s$ straight, its extreme distal part slightly curved toward wing margin; nervulus $(\mathrm{cu}-a)$ postfurcal by about $0.1-0.2 \times$ its length; postnervulus (abscissa of $C u 1$ between $1 m-c u$ and $C u 1 a+C u 1 b$ ) intercepted distinctly above middle by $\mathrm{Cu} 1 \mathrm{a}$; hairs of subbasal and first subdiscal cells conspicuously sparse as compared to other areas of fore wing. Hind wing with nervellus ( $c u-a+$ abscissa of $\mathrm{Cu} 1$ between $\mathrm{M}$ and $\mathrm{Cu}-a$ ) strongly reclivous, intercepted by discoidella (distal abscissa of $\mathrm{Cu} 1$ ) distinctly above its middle; discoidella spectral, proximally connected to nervellus. Coxae granulate with superficial, weak punctures. Hind femur long and slender, almost $7 \times$ as long as high. Inner spur of hind tibia about $0.8 \times$ as long as first tarsomere of hind tarsus. Tarsal claws small and short, little longer than arolium, basal half with small but distinct pecten.

Metasoma: Metasoma strongly compressed, very finely granulate to shagreened with short greyish to brownish hairs. First tergite very long and slender, upcurved, more than $7 \times$ as long as width of its apical margin, $1.2-1.3 \times$ as long as second tergite, without glymma; dorsomedian carina of first tergite missing; postpetiolus bulging. Second tergite long and slender, ca. $5 \times$ as long as its apical width; thyridium elongate, its distance from basal margin of tergite about $3 \times$ as long as its length. Posterior margins of third and following tergites medially weakly and widely concave, posterior margin of seventh tergite strongly excised. Ovipositor sheath short, subequal to apical depth of metasoma; ovipositor strong, compressed, dorsal preapical notch distinct, lower valve abruptly narrowed before apex.

Colour: Antenna dark brown, scapus and pedicellus ventrally golden yellowish, dorsally yellowish brown. Head black except palpi and mandible yellow, mandibular teeth dark reddish brown. Mesosoma black except tegula light brownish. Metasoma predominantly ferruginous with black to dark brown patches; first tergite yellowish brown, peti-

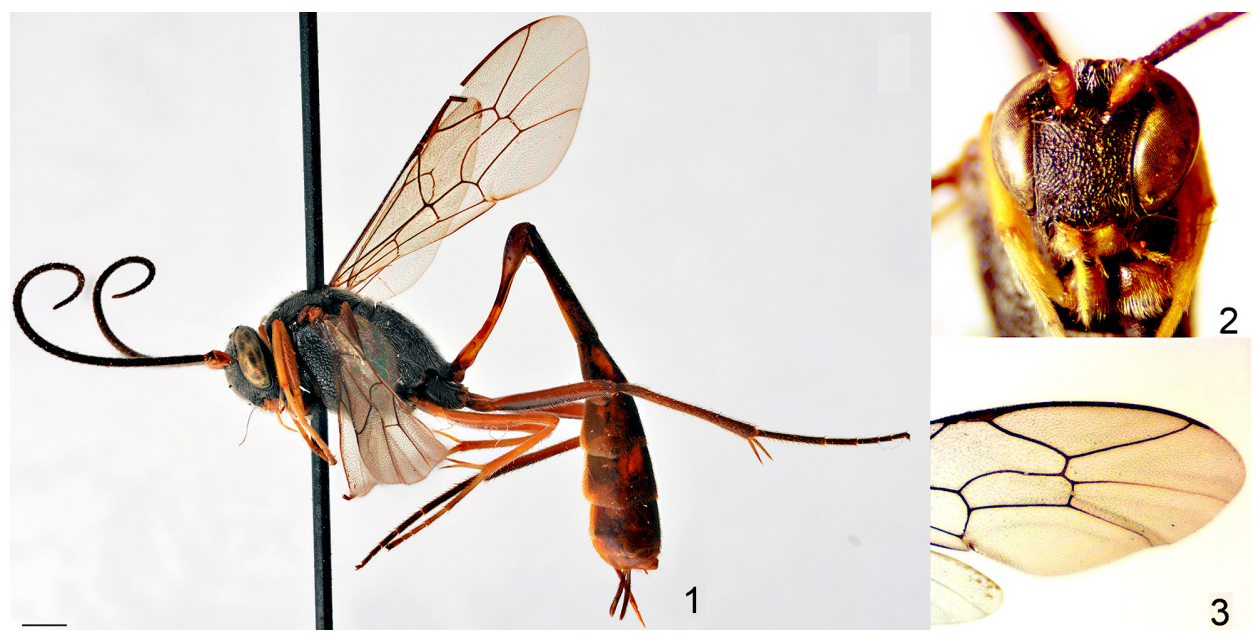

Figs 1-3. Charops aeruginosus sp. n., holotype: 1 = lateral habitus, $2=$ head, frontal view, $3=$ fore wing, distal abscissa of $R s$ (scale bar on Fig. $1=1 \mathrm{~mm}$ ) 
olus basally and/or apically with a blackish band or patch, postpetiolus darker brownish; second tergite predominantly blackish, laterally light reddish brown from thyridium to black apical margin; third tergite rusty reddish brown, dorsally blackish, laterally tinged with blackish to dark brown patches; fourth and following tergites rusty reddish brown, dorsally blackish to dark brown; ovipositor sheath dark brown. Wings weakly infuscate, wing veins and pterostigma dark brown. Fore leg: coxa black, ventrally and apically extensively yellowish; trochanter and trochantellus yellowish; femur entirely light orange; tibia and tarsus yellowish, apical tarsomeres brownish. Middle leg: coxa black; trochanter brown to yellowish brown; trochantellus yellowish brown; femur entirely orange; tibia reddish yellow; tarsus brownish except basal third of first tarsomere ventrally yellowish. Hind leg: coxa black; trochanter dark brown with narrow yellowish brown margin; trochantellus brownish; femur rusty reddish, ventrally darker brownish; tibia brown, without basal yellowish spot, apically slightly darkened; tarsus dark brown.

Male: Unknown.

Distribution - Currently known from Taiwan.

Etymology - The specific epithet aeruginosus is the masculine form of the Latin adjective aeruginosus, $-a$, - um meaning copper rust-coloured; it refers to the colouration of metasoma and legs of the new species.

Remarks - By using the identification key of Gupta and Maheshwary (1977), Charops aeruginosus sp. n. runs to couplet 10 together with the other species of the "Brachypterus Group" sensu Gupta and Maheshwary (1971, 1977), but without further matching to either half of couplet 10. Among the Oriental species of the genus the new species is somewhat similar to Charops hersei Gupta et Maheshwary, 1971 known from India and Sri Lanka; however, this species could be readily distinguished from the new species by its pale yellowish fore femur, pale yellowish middle femur with dark brown patches ventrally in the middle, entirely black hind femur, blackish hind tibia, somewhat darker metasoma, different sculpture of mesopleuron (upper half densely covered with irregular wrinkles, lower half rugose), and absent lateromedian longitudinal carinae of propodeum (in Charops aeruginosus sp. n. lateromedian longitudinal carinae present but weak).

\section{Neotropical region}

\section{Charops lucianae Santos et Onody, 2019}

Material - Argentina, Metan (Salta) [=Salta Province, San José de Metán], [1]906, leg. [Á.] Vezényi, 1 ㅇ.

Remarks - First record for Argentina. This species was only recently described from Brazil (SANTos et al. 2019). 


\section{Palaearctic region}

\section{Charops cantator (DeGeer, 1778)}

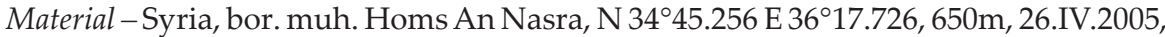
leg. N. Rahmé, A. Márkus, A. Kotán \& A. Podlussány, 1 đ.

Remarks - First record for Syria. This species is widely distributed in the Palaearctic region (Yu et al. 2012).

\section{Afrotropical region}

\section{Charops armatus Seyrig, 1935}

Material - Abyssinia [= Ethiopia], Marako [= Maraquo], III.1912, leg. [Ö.] Kovács, 1 $\widehat{\text {. }}$

Remarks - First record for Ethiopia. This species was known from Kenya and Tanzania (Seyrig 1935, Yu et al. 2012). See Discussion regarding the taxonomic status of this species.

\section{Charops ater Szépligeti, 1908}

Remarks - This Afrotropical species, described from Tanzania and later found also in Kenya (SzÉpligeti 1908, SeYrig 1935), is erroneously reported also from Indonesia in Yu and Horstmann (1997) and Yu et al. (2012); the reason of the false Oriental distribution record is confusion with an Indonesian species with secondary homonym name: Charops ater Szépligeti, 1910, described as Agrypon atrum Szépligeti, 1910, later moved into combination with Charops (SzÉPligetr 1910, Townes et al. 1961). Due to homonymy, the Indonesian species originally described as Agrypon atrum Szépligeti, 1910 received the replacement name Charops cavendishae Kittel, 2016, while Charops ater Szépligeti, 1908 is a valid name for the Afrotropical species (KITTEL 2016).

\section{Charops cantator (DeGeer, 1778)}

Remarks - This species is widely distributed in the Palaearctic region; however, Yu et al. (2012) also list a suspicious single distributional record from South Africa citing Dalla TorRe (1902). However, by checking the cited species entry in Dalla Torre (1902)'s catalogue, only "Afr.: Cap." is indicated as distribution of this otherwise Palaearctic species ("Eur." is not at all mentioned despite Charops cantator (DeGeer, 1778) was described from Sweden); hence, it clearly seems to be an erroneous record of the catalogue. Ad- 
ditionally, to my best knowledge, no other actual Afrotropical record of this species was ever documented with specimen and published. Hence, nothing confirms Dalla Torre (1902) most probably erroneous entry regarding the occurrence of Charops cantator (DeGeer, 1778) in the Afrotropical region. For these reasons, until further evidence may prove its occurrence, Charops cantator (DeGeer, 1778) is to be rejected from the list of Charops species known from the Afrotropical region.

Charops diversipes Roman, 1910

Material - Uganda, Mujenje, VII-VIII.1913, leg. [K.] Katona [= K. Kittenberger], 3 q.

Remarks - First record for Uganda. This species was known from Kenya, Tanzania, and Ghana (Seyrig 1935, Duodu \& Lawson 1983, Yu et al. 2012). See Discussion regarding the taxonomic status of this species.

\section{Charops electrinus sp. n.}

(Figs 4-6)

Type material - Holotype: female, Uganda, Mujenje, VIII.1913, leg. [K.] Katona [= K. Kittenberger]; specimen card-mounted, Id. No. HNHM-HYM 153213. - The holotype specimen is deposited in the Hymenoptera Collection of HNHM (Budapest, Hungary).

Diagnosis - Charops electrinus sp. n. could be easily identified by its colouration (tegula pale yellow, fore and middle legs except coxae ivory, hind femur brown, hind tibia brown with distinct basal yellowish spot, metasoma including apical tergites amber yellow with rather narrow brownish dorsal patches), apically strongly curved distal abscissa of $R s$, basally developed propodeal carination, and small size.

Description - Female (Figs 4-6). Body length ca. $7 \mathrm{~mm}$, fore wing length ca. $4 \mathrm{~mm}$.

Head: Antenna with 32 flagellomeres; first flagellomere ca. $2.7 \times$ as long as apically wide; preapical flagellomeres little longer than wide. Head lenticular, matt, its anterior surface rugose-punctate, posterior surface granulate with indistinct punctures, and with dense, moderately long, greyish hairs. Ocular-ocellar distance $0.3 \times$ as long as ocellus diameter, posterior ocellar distance about as long as ocellus diameter. Inner eye orbits strongly indented and weakly convergent ventrally. Malar space very short, ca. $0.25 \times$ as long as basal width of mandible. Face conspicuously narrow, weakly convex in profile, narrowed ventrally, minimal width of face ca. $0.5 \times$ as long as eye length. Clypeus very weakly separated from face, convex in profile, its apical margin convex, rather sharp. Mandible short, high, lower margin of mandible with rather wide flange from teeth toward base, flange abruptly narrowed at teeth, mandibular teeth of equal length.

Mesosoma: Mesosoma with dense, moderately long, greyish hairs. Pronotum finely granulate with strong transverse wrinkles, its upper edge and posterior corner rugose; 
epomia distinct. Mesoscutum coarsely rugose, weakly convex in profile, little shorter than wide, notaulus not developed. Scuto-scutellar groove very narrow. Scutellum coarsely rugose, wide, flat, medially widely impressed, concave, lateral carina indistinct. Mesopleuron coarsely rugose with short transverse wrinkles along posterior margin; mesopleural suture not impressed. Epicnemial carina complete, pleural part bent to anterior margin of mesopleuron reaching it about its middle height, transversal part (i.e. part at the level of sternaulus running through the epicnemium to the ventral edge of pronotum) developed but relatively weak, ventral part (behind fore coxae) complete, slightly elevated. Sternaulus indistinct. Posterior transverse carina of mesosternum complete, medially excised, submedially developed into a pair of tooth-like, triangular processes. Metanotum rugose, short, about $0.25 \times$ as long as scutellum. Metapleuron coarsely rugose; juxtacoxal carinae distinct, strong; submetapleural carina complete, strong. Pleural carina of propodeum strong; propodeal spiracle elongate, narrow, separated from pleural carina by about twothird of its length, connected to pleural carina by a distinct ridge. Propodeum coarsely rugose with transverse and irregular wrinkles, long, its apex reaching little beyond middle length of hind coxa. Lateromedian longitudinal carinae distinct on basal half of propodeum, costula distinct, propodeal carinae on apical half of propodeum obsolescent. Fore wing without areolet, 3rs- $m$ missing; pterostigma long and narrow; second recurrent vein $(2 m-c u)$ distal to intercubitus $(2 r s-m)$ by about $0.8 \times$ length of intercubitus; distal abscissa of Rs straight, its distal part strongly curved toward wing margin; nervulus ( $\mathrm{cu}-a)$ postfurcal by about its width; postnervulus (abscissa of $\mathrm{Cu} 1$ between $1 \mathrm{~m}-\mathrm{cu}$ and $\mathrm{Cu} 1 \mathrm{a}+\mathrm{Cu} 1 \mathrm{~b}$ ) intercepted distinctly above middle by $\mathrm{Cu} 1 \mathrm{a}$. Hind wing with nervellus ( $\mathrm{cu}-a+$ abscissa of

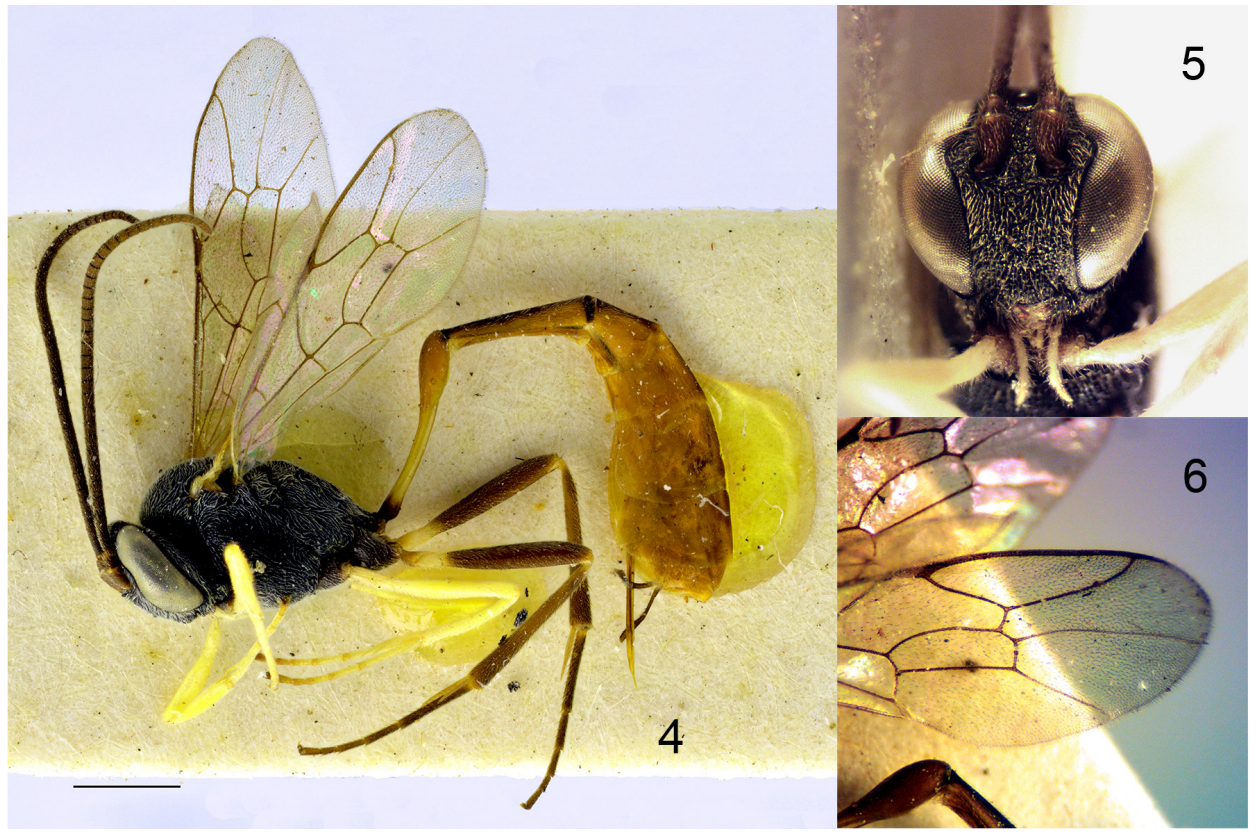

Figs 4-6. Charops electrinus sp. n., holotype: $4=$ lateral habitus, $5=$ head, frontal view, $6=$ fore wing, distal abscissa of $R s$ (scale bar on Fig. $4=1 \mathrm{~mm}$ ) 
$\mathrm{Cu} 1$ between $\mathrm{M}$ and $\mathrm{cu}-a$ ) reclivous, intercepted by discoidella (distal abscissa of $\mathrm{Cu} 1$ ) little above its middle; discoidella spectral, proximally connected to nervellus. Coxae granulate with superficial, weak punctures. Hind femur long and slender, about $6.5 \times$ as long as high. Inner spur of hind tibia about $0.7 \times$ as long as first tarsomere of hind tarsus. Tarsal claws small and short, little longer than arolium, basal half with small but distinct pecten.

Metasoma: Metasoma strongly compressed, very finely granulate with short greyish to whitish hairs. First tergite very long and slender, upcurved, more than $7 \times$ as long as width of its apical margin, $1.25 \times$ as long as second tergite, without glymma; dorsomedian carina of first tergite missing; postpetiolus bulging. Second tergite long and slender, ca. $5 \times$ as long as its apical width; thyridium oval, its distance from basal margin of tergite about $3 \times$ as long as its length. Posterior margins of third and following tergites medially weakly and widely concave, posterior margin of seventh tergite strongly excised. Ovipositor sheath short, subequal to apical depth of metasoma; ovipositor strong, compressed, dorsal preapical notch distinct, lower valve abruptly narrowed before apex.

Colour: Antenna dark brown to brown, scapus and pedicellus brown with somewhat paler, rather narrow apical margins. Head black, basal half of mandible blackish, apical half yellowish with reddish brown teeth, palpi ivory. Mesosoma black except tegula pale yellow. Metasoma including apical tergites predominantly amber yellow with rather narrow brownish dorsal patches; petiolus yellowish, at extreme basal part blackish, postpetiolus amber yellow; second tergite with narrow dark brown apical margin. Wings subhyaline, wing veins and pterostigma light brown. Fore leg: coxa predominantly blackish to dark brown, apically narrowly yellowish; rest of leg ivory, apical tarsomeres yellowish brown. Middle leg: coxa blackish to dark brown; rest of leg ivory, apical tarsomeres yellowish brown. Hind leg: coxa blackish to dark brown; trochanter yellow, basally brownish yellow; trochantellus ivory; femur brown; tibia brown with distinct basal pale yellow spot; tarsus brown.

Male: Unknown.

Distribution - Currently known from Uganda.

Etymology - The specific epithet electrinus is the masculine form of the Latin adjective electrinus, $-a$, -um meaning amber-coloured; it refers to the colouration of metasoma of the new species.

Remarks - Among the Afrotropical species of the genus the new species is somewhat similar to Charops spinitarsis Cameron, 1905; however, this species could be distinguished from the new species by its distinctly reddish hind femur and hind tibia, predominantly rusty reddish metasoma, apically at most slightly curved distal abscissa of $R s$, and larger size (ca. $10 \mathrm{~mm}$ ). Due to its light colouration and small size Charops electrinus sp. n. is superficially similar to the East Asian-Australian species Charops bicolor (Szépligeti, 1906); however, this species could be readily distinguished from the new species by its predominantly yellowish fore and middle coxae, yellowish brown hind femur and tibia, ventrally bright yellow scapus and pedicellus, and different, faint propodeal carination. See Discussion for the identification key of Afrotropical Charops species. 


\section{Charops juliannae sp. n.}

(Figs 7-9)

Type material - Holotype: female, Africa or. [= Africa orientalis], Arusha-Ju [= Tanzania, Arusha], XI.1905, leg. [K.] Katona [= K. Kittenberger]; specimen pinned, antennae damaged, Id. No. HNHM-HYM 153214. - The holotype specimen is deposited in the Hymenoptera Collection of HNHM (Budapest, Hungary).

Diagnosis - Charops juliannae sp. n. could be easily identified by its colouration (tegula black, fore leg except coxae yellow, middle femur predominantly blackish with yellow patches, middle tibia yellow, hind femur black, hind tibia blackish to dark brown with distinct, elongate basal yellowish spot, hind trochantellus predominantly brown, dorsally and along apical margin narrowly yellowish, metasoma including apical tergites predominantly reddish with narrow dark brownish dorsal patches), apically moderately strongly curved distal abscissa of $R s$, on basal half weakly developed and on apical half obsolescent lateromedian longitudinal carinae of medially weakly and narrowly impressed propodeum.

Description - Female (Figs 7-9). Body length ca. $10 \mathrm{~mm}$, fore wing length ca. $5.5 \mathrm{~mm}$.

Head: First flagellomere ca. $3.3 \times$ as long as wide apically. Head lenticular, matt, its anterior surface rugose, posterior surface granulate with weak punctures, and with dense, moderately long, greyish hairs. Ocular-ocellar distance $0.7 \times$ as long as ocellus diameter, posterior ocellar distance about as long as ocellus diameter. Inner eye orbits strongly indented and weakly convergent ventrally. Malar space short, ca. $0.4 \times$ as long as basal width of mandible. Face narrow, almost flat in profile, narrowed ventrally, minimal width of face ca. $0.65 \times$ as long as eye length. Clypeus very weakly separated from face, convex in profile, its apical margin convex, sharp. Mandible short, high, lower margin of mandible with rather wide flange from teeth toward base, flange abruptly narrowed at teeth, mandibular teeth of equal length.

Mesosoma: Mesosoma with dense, moderately long, greyish hairs. Pronotum with strong transverse wrinkles, its upper edge and posterior corner rugose; epomia distinct. Mesoscutum coarsely rugose, convex in profile, $0.8 \times$ as long as wide, notaulus not developed. Scuto-scutellar groove very narrow. Scutellum coarsely rugose, wide, medially rather widely impressed, concave, lateral carina indistinct. Mesopleuron coarsely rugosereticulate with distinct transverse wrinkles on upper half; mesopleural suture not impressed. Epicnemial carina complete, pleural part bent to anterior margin of mesopleuron reaching it about its middle height, transversal part (i.e. part at the level of sternaulus running through the epicnemium to the ventral edge of pronotum) developed, ventral part (behind fore coxae) complete, slightly elevated. Sternaulus indistinct. Posterior transverse carina of mesosternum complete, medially excised, submedially developed into a pair of tooth-like, triangular processes. Metanotum rugose, short, about $0.25 \times$ as long as scutellum. Metapleuron coarsely rugose; juxtacoxal carinae distinct, strong; submetapleural carina complete, strong. Pleural carina of propodeum strong; propodeal spiracle strongly elongate, narrow, separated from pleural carina by about $0.6 \times$ its length, connected to pleural carina by a distinct ridge. Propodeum coarsely rugose with transverse wrinkles, 
medially distinctly and narrowly impressed, long, its apex reaching middle length of hind coxa. Lateromedian longitudinal carinae weakly developed on basal half of propodeum, costula rather weak, carinae on apical half of propodeum obsolescent. Fore wing without areolet, $3 r s-m$ missing; pterostigma long and narrow; second recurrent vein $(2 m-c u)$ distal to intercubitus $(2 r s-m)$ by about $0.7 \times$ length of intercubitus; distal abscissa of $R s$ almost straight, its distal part distinctly but moderately strongly curved toward wing margin; nervulus ( $c u-a$ ) postfurcal by about its width; postnervulus (abscissa of $C u 1$ between $1 m-c u$ and $C u 1 a+C u 1 b)$ intercepted distinctly above middle by $C u 1 a$. Hind wing with nervellus ( $c u-a+$ abscissa of $\mathrm{Cu} 1$ between $M$ and $c u-a$ ) weakly reclivous, intercepted by discoidella (distal abscissa of $C u 1$ ) at about its lower third; discoidella spectral, proximally connected to nervellus. Coxae coarsely granulate with superficial, weak punctures. Hind femur long and slender, about $6 \times$ as long as high. Inner spur of hind tibia about $0.65 \times$ as long as first tarsomere of hind tarsus. Tarsal claws small and short, little longer than arolium, basal half with small but distinct pecten.

Metasoma: Metasoma strongly compressed, very finely granulate with short greyish to brownish hairs. First tergite very long and slender, moderately upcurved, more than $7 \times$ as long as width of its apical margin, $1.2 \times$ as long as second tergite, without glymma; dorsomedian carina of first tergite missing; postpetiolus moderately bulging. Second tergite long and slender, ca. $5 \times$ as long as its apical width; thyridium oval, its distance from basal margin of tergite about $3.5 \times$ as long as its length. Posterior margins of third and following tergites medially weakly and widely concave, posterior margin of seventh tergite strongly

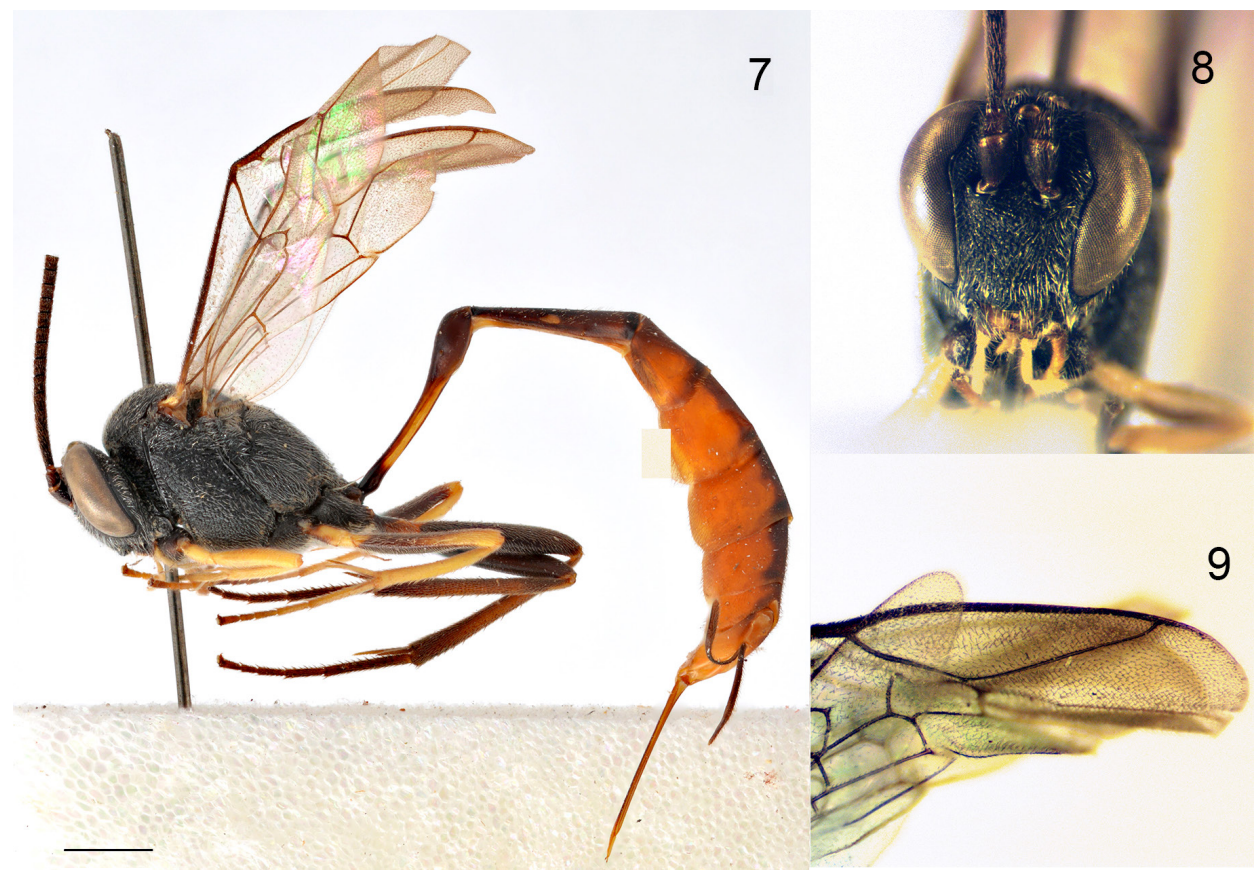

Figs 7-9. Charops juliannae sp. n., holotype: $7=$ lateral habitus, $8=$ head, frontal view, $9=$ fore wing, distal abscissa of $R s$ (scale bar on Fig. $7=1 \mathrm{~mm}$ ) 
excised. Ovipositor sheath little longer than apical depth of metasoma; ovipositor strong, compressed, dorsal preapical notch distinct, lower valve abruptly narrowed before apex.

Colour: Antenna dark brown, scapus dark brown with somewhat paler, rather narrow apical margin, pedicellus dark brown. Head black, basal half of mandible blackish, apical half yellowish with reddish brown teeth, palpi ivory. Mesosoma including tegula black. Petiolus yellowish brown, at extreme basal part blackish, postpetiolus dark brown; second tergite dark brown, subapically indistinctly dark reddish brown, its narrow apical margin black; metasoma from third tergite, including apical tergites, predominantly reddish with narrow dark brownish dorsal patches. Wings weakly infuscate, wing veins and pterostigma dark brown. Fore leg: coxa blackish; rest of leg yellow, apical tarsomeres yellowish brown. Middle leg: coxa black; trochanter ventrally brown, dorsally yellowish; trochantellus yellow; femur predominantly blackish with yellow patches; tibia yellow; tarsus yellow to yellowish brown, apical tarsomeres brownish. Hind leg: coxa black; trochanter blackish with narrowly yellowish brown apical margin; trochantellus predominantly brown, dorsally and along apical margin narrowly yellowish; femur black; tibia blackish to very dark brown with distinct, elongate basal yellowish spot; tarsus dark brown.

Male: Unknown.

Distribution - Currently known from Tanzania.

Etymology - The new species is gratefully dedicated to Istvánné Domonkos (her maiden name is Julianna Szabó; she is known as "Jutka" among colleagues), preparator and assistant of the Hymenoptera Collection in the Hungarian Natural History Museum since 1994. For more than 25 years, she has beautifully mounted tens of thousands of hymenopteran specimens with outstanding professionalism and vocation, has taken exceedingly good care of the collection, and has been invaluable assistance and an invaluable person in all activities of the Hymenoptera Collection.

Remarks - Among the Afrotropical species of the genus the new species is most similar to Charops cariniceps Cameron, 1906; however, this species could be distinguished from the new species by its entirely black apical tergites, partly reddish fore and middle femora, reddish yellow hind trochantellus, apically at most slightly curved distal abscissa of $R s$, and complete and strong lateromedian carinae of propodeum. Charops juliannae sp. n. is also superficially similar to Charops spinitarsis Cameron, 1905; however, this species could be readily distinguished from the new species by its yellow tegula and reddish hind femur and tibia. See Discussion for the identification key of Afrotropical Charops species.

\section{DISCUSSION}

With the above described three new species, the total number of valid Charops species has been increased to 38 at a worldwide level. The number of species known from the Oriental region changed from 12 to 13 with the addition of Charops aeruginosus sp. $\mathrm{n}$. The Afrotropical fauna has been increased with two new species (Charops electrinus sp. n. and Charops juliannae sp. n.); 
however, the single Afrotropical record of Charops cantator (DeGeer, 1778) has been rejected (see above). Hence, by adding two species and removing one, currently, 12 valid Charops species can be listed from the Afrotropical region. The current taxonomic status of the Afrotropical species of the genus is confirmed (i.e. unchanged according to Yu and Horstmann (1997)'s catalogue), with the following argument about three species.

By checking the type material of Charops diversipes Roman, 1910 and Charops armatus Seyrig, 1935 one can be aware that these species are remarkably similar, and Charops armatus Seyrig, 1935 may even be a junior synonym of Charops diversipes Roman, 1910. There are only minor differences between the two species and their known distributions are greatly overlapping (see in the identification key below). Nevertheless, I could examine very few specimens besides type material, hence I was not able to form a decisive opinion whether the observed differences represent only intraspecific variability or distinct species. Additionally, the situation becomes more complicated by considering Charops flavipes Brullé, 1846; this species was described from Senegal (BRullé, 1846), but its type material is lost (Townes \& Townes, 1973), and based only on its short, poorly detailed original description it could not be excluded that Charops flavipes Brullé, 1846 may be conspecific with Charops armatus Seyrig, 1935 or Charops diversipes Roman, 1910 (or with both if future studies would consider them synonyms). Since the original type material of Charops flavipes Brullé, 1846 can not be examined, no clarification or judgement could be made. For the above reasons, I decided to remain the taxonomic status of these species unchanged at present; future researchers with access to more non-type specimens may be able to clarify the status of these species, or at least in the case of Charops diversipes Roman, 1910 and Charops armatus Seyrig, 1935.

\section{IDENTIFICATION KEY TO THE AFROTROPICAL CHAROPS SPECIES}

No comprehensive identification key has been published to the Afrotropical Charops species so far, only a few small keys with partial set of species of the region (SzÉPLIGETi 1908, SEYRIg 1935). An identification key to the currently accepted Afrotropical species of the genus is provided below. It should be considered preliminary and used with caution, firstly as it is principally based on the examination of type material, hence the level of intraspecific variability is little understood; secondly as most probably there might be still undescribed species in the region. Supporting but not distinguishing characters are given in parentheses, distributional information in brackets. 
1 Hind tibia distinctly longitudinally two-coloured, externally ivory from base to almost its entire length, internally reddish brown (fore and middle legs yellow, hind femur reddish brown, petiolus partly and middle tergites extensively reddish, tegula yellow, mandible yellow, scapus and pedicellus extensively yellowish, distal abscissa of $R s$ straight) [Ethiopia, Somalia, Sudan]

Ch. breviceps Kriechbaumer, 1884

- Hind tibia rather uniformly coloured (black, brown or reddish) 2

2 All femora reddish, tegula dark

- $\quad$ Leg colouration different, not all femora and tibiae reddish (tegula dark or yellow)

3 Metasoma except first tergite black, malar space distinctly longer than $0.5 \times$ basal width of mandible, fore wing strongly infuscate, brownish (distal abscissa of $R s$ apically weakly curved) [Tanzania]

Ch. fuliginosus Szépligeti, 1908

- Metasoma almost entirely reddish, extreme basal part of petiolus, dorsal patch and narrow apical margin of second tergite blackish, malar space subequal to $0.5 \times$ basal width of mandible, fore wing weakly infuscate (distal abscissa of Rs apically weakly curved) [Tanzania]

Ch. obscurior Roman, 1910

4 All legs black (metasoma, tegula, mandible black, distal abscissa of $R s$ apically strongly curved) [Kenya, Tanzania] Ch. ater Szépligeti, 1908

- Leg colouration different, not all legs black 5

5 Hind femur and tibia reddish 6

- Hind femur and tibia blackish or brown 7

6 Metasoma including apical tergites laterally rusty reddish with narrow dark brown dorsal patches, hind trochanter partly and hind trochantellus yellowish (fore and middle legs yellowish, tegula yellow, distal abscissa of Rs apically slightly curved) [Kenya, South Africa, Tanzania]

Ch. spinitarsis Cameron, 1905

- Metasoma predominantly blackish or blackish with extensively reddish middle tergites, at least apical tergites entirely black, hind trochanter dark, hind trochantellus reddish (fore and middle legs yellowish, tegula yellow, distal abscissa of Rs apically weakly curved) [South Africa]

Ch. brevipennis (Cameron, 1906)

7 Metasoma entirely black or blackish, at most with very dark reddish brown patches on middle tergites (hind femur and tibia blackish, tegula 
black, fore and middle femora and tibiae predominantly yellowish with more or less extensive dark patches on middle femora)

- Metasoma extensively reddish or amber yellow (hind femur and tibia black, blackish or brown, tegula black or pale yellow)

$8^{*} \quad$ Distal abscissa of $R s$ apically strongly curved, hind trochantellus predominantly dark, basal yellowish spot of hind tibia rather indistinct, mandible mostly black, reddish brown around teeth, propodeal carinae weak (posterior transverse carina of mesosternum submedially developed into a pair of tooth-like, distinct processes) [Ghana, Kenya, Tanzania, Uganda]

Ch. diversipes Roman, 1910

- Distal abscissa of Rs apically weakly curved, hind trochantellus predominantly yellowish, basal yellowish spot of hind tibia rather distinct, bright, mandible almost entirely yellow with reddish brown teeth, propodeal carinae somewhat stronger (posterior transverse carina of mesosternum submedially developed into a pair of tooth-like, distinct processes) [Ethiopia, Kenya, Tanzania]

Ch. armatus Seyrig, 1935

9 Tegula pale yellow, metasoma including apical tergites amber yellow with rather narrow brownish dorsal patches, hind femur brown, hind tibia brown with distinct basal yellowish spot (fore and middle legs ivory except coxae, distal abscissa of Rs apically strongly curved, small species, body length ca. $7 \mathrm{~mm}$ ) [Uganda]

Ch. electrinus sp. $\mathrm{n}$.

- Tegula dark, metasoma extensively reddish, not amber yellow, hind femur and hind tibia darker, black to very dark brown (larger species, body length ca. $10 \mathrm{~mm}$ )

10 Metasoma including apical tergites reddish with narrow dark brownish dorsal patches, fore femur yellow, middle femur predominantly blackish with yellow patches, hind trochantellus predominantly brown, postpetiolus dark brown, lateromedian carinae obsolescent on posterior half of propodeum, distal abscissa of $R s$ apically distinctly and moderately strongly curved [Tanzania]

Ch. juliannae sp. n.

- Metasoma extensively reddish with entirely black apical tergites, fore and middle femora partly yellowish and partly reddish, hind trochantellus reddish yellow, postpetiolus predominantly reddish, lateromedian carinae rather strong along entire length of propodeum, apically diver-

\footnotetext{
* According to its original description Charops flavipes Brullé, 1846 [Senegal] would also key out in couplet 8 , however, its reliable separation from the other two species of the couplet is not possible given the lack of type material and properly detailed information (see Discussion above for more details).
} 
gent, distal abscissa of Rs almost straight, at extreme apex slightly curved [South Africa, Zimbabwe]

Ch. cariniceps Cameron, 1906

Acknowledgements - I am grateful to Hege Vårdal (Swedish Museum of Natural History, Stockholm) for his help in checking relevant type material. I thank Tamás Németh (HNHM, Budapest) for some of the photos (Figs 1, 4, 7). The author was supported by the Hungarian Government, Ministry of Human Capacities (Emberi Erőforrások Minisztériuma) in the frame of the NTP-NFTÖ-19-B-0007 scholarship (Nemzet Fiatal Tehetségeiért Ösztöndíj).

\section{REFERENCES}

AshmeAd, W. H. (1890): Description of new Ichneumonidae in the collection of the U.S. National Museum. - Proceedings of the United States National Museum 12: 387-451. https:// doi.org/10.5479/si.00963801.12-779.387

Brullé, M. A. (1846): Tome Quatrième. Des Hyménoptères. Les Ichneumonides. Pp. 56-521. In: Lepeletier, A. L. M. (ed.): Histoire Naturelles des Insectes. - Librairie encyclopédique de Roret, Paris.

Cameron, P. (1906): Descriptions of new species of parasitic Hymenoptera chiefly in the collection of the South African Museum, Cape Town. - Annals of the South African Museum 5: 17-186.

Cameron, P. (1905): On some new genera and species of Hymenoptera from Cape Colony and Transvaal. - Transactions of the South African Philosophical Society 15: 195-257. https://doi.org/10.1080/21560382.1904.9626440

Chol, J.-K. \& LeE, J.-W. (2008): Taxonomic study of the genus Charops Holmgren (Hymenoptera: Ichneumonidae: Campopleginae) from the eastern Palaearctic region. - Entomological Research (Seoul) 38(2): 157-164. https://doi.org/10.1111/j.1748-5967.2008.00152.x

Cresson, E. T. (1865): On the Hymenoptera of Cuba. - Proceedings of the Entomological Society of Philadelphia 4: 1-200.

Duodu, Y. A. \& Lawson, B. W. L. (1983): Natural enemies of Acraea terpsicore (Lepidoptera: Nymphalidae) in Ghana with particular reference to the parasite Charops diversipes (Hymenoptera: Ichneumonidae). - Entomophaga 28(3): 271-276. https://doi. org/10.1007/BF02372177

Gauld, I. D. (1991): The Ichneumonidae of Costa Rica, 1. Introduction, keys to subfamilies, and keys to the species of the lower Pimpliform subfamilies Rhyssinae, Poemeniinae, Acaenitinae and Cylloceriinae. Memoirs of the American Entomological Institute 47: $1-589$.

Gauld, I. D., Wahl, D., Bradshaw, K., Hanson, P. \& Ward, S. (1997): The Ichneumonidae of Costa Rica, 2. Introduction and keys to species of the smaller subfamilies, Anomaloninae, Ctenopelmatinae, Diplazontinae, Lycorininae, Phrudinae, Tryphoninae (excluding Netelia) and Xoridinae, with an appendix on the Rhyssinae. - Memoirs of the American Entomological Institute 57: 1-485.

Girault, A. A. (1925): Records and distributions of Australian Ophioninae (Ichneumonflies). - Queensland Agricultural Journal 24: 538-541. 
Gupta, V. K. \& Maheshwary, S. (1977): Ichneumonologia Orientalis. Part IV. The tribe Porizontini (=Campoplegini) (Hymenoptera: Ichneumonidae). - Oriental Insects Monographs 5: 1-267.

Gupta, V. K. \& Maheshwary, S. (1971): Indian species of Charops Holmgren (Hymenoptera: Ichneumonidae). - Oriental Insects 4: 453-480. https://doi.org/10.1080/0030531 6.1970 .10433983

Harris, R. A. (1979): A glossary of surface sculpturing. - Occasional Papers in Entomology 28: $1-31$.

He, J. H., Chen, X. X. \& MA, Y. (1996): Hymenoptera: Ichneumonidae. Economic Insect Fauna of China. - Science Press, Beijing, 697 pp.

Horstmann, K. (2008): Neue westpalearktische Arten der Campopleginae (Hymenoptera: Ichneumonidae). - Zeitschrift der Arbeitsgemeinschaft Oesterreichischer Entomologen 60: $3-27$.

Jonathan, J. K. (1999): Hymenoptera: Ichneumonidae. Fauna of West Bengal. Part. 8. Insecta (Trichoptera, Thysanoptera, Neuroptera, Hymenoptera and Anoplura). - Zoological Survey of India, Calcutta, $442 \mathrm{pp}$.

Kittel, R. N. (2016): Eighty-nine Replacement Names for Braconidae and Ichneumonidae (Insecta: Hymenoptera: Ichneumonoidea). - Japanese Journal of Systematic Entomology 22(2): 161-174.

MAgretti, P. (1884): Roccolte imenotterologiche nell'Africa orientale. - Bollettino della Societa Entomologica Italiana 15: 241-253.

Maheshwary, S. (1971): On a collection of Charops from Taiwan (Hymenoptera: Ichneumonidae). - Oriental Insects 5(3): 317-322. https://doi.org/10.1080/00305316.1971.104 34019

Roman, A. (1910): Notizen zur Schlupfwespensammlung des schwedischen Reichsmuseums. - Entomologisk Tidskrift 31: 109-196. https://doi.org/10.5962/bhl.part.13757

Santos, A. D., Onody, H. C. \& Brandão, C. R. F. (2019): Taxonomic contributions to the genus Charops Holmgren, 1859 (Hymenoptera: Ichneumonidae), with description of seven new species from Brazil. - Zootaxa 4619(1): 45-76. https://doi.org/10.11646/ zootaxa.4619.1.2

Seyrig, A. (1935): Mission scientifique de l'Omo. Tome III. Fascicule 18. Hymenoptera, II. Ichneumonidae: Cryptinae, Pimplinae, Tryphoninae et Ophioninae. - Mémoires $d u$ Muséum National d'Histoire Naturelle 4: 1-100.

SzÉpligeti, Gy. (1906): Neue exotische Ichneumoniden aus der Sammlung des Ungarischen National Museums. - Annales musei nationalis hungarici 4: 119-156.

Szépligeti, GY. (1908): Hymenoptera: Braconidae \& Ichneumonidae. Pp. 25-96. In: SJosteDTs, Y. (ed.): Wissenschaftliche Ergebnisse der Schwedischen Zoologischen Expedition nach dem Kilimandjaro, dem Meru und den umgebenden Massaisteppen. - Almoqvist \& Wiksells, Uppsala.

SzÉPLIGETI, Gy. (1910): E. Jacobons'sche Hymenopteren aus Java und Krakatau. Braconiden und Ichneumoniden. - Notes from the Leyden Museum 32: 85-104.

Townes, H. \& Townes, M. (1973): A catalogue and reclassification of the Ethiopian Ichneumonidae. - Memoirs of the American Entomological Institute 19: 1-416.

Townes, H. (1969): The genera of Ichneumonidae. Part 1. - Memoirs of the American Entomological Institute 11: 1-300.

Townes, H. (1970a): The genera of Ichneumonidae. Part 3. - Memoirs of the American Entomological Institute 13: 1-307. 
Townes, H. (1970b): A review of the Ichneumonidae described by Girault (Hymenoptera). - Proceedings of the Entomological Society of Washington 72: 458-470.

Townes, H., Townes, M. \& Gupta, V. K. (1961): A catalogue and reclassification of the IndoAustralian Ichneumonidae. - Memoirs of the American Entomological Institute 1: 1-522.

van Noort, S. (2019): WaspWeb: Hymenoptera of the Afrotropical region. Available from: http://www.waspweb.org [accessed 2 February 2020]

Yu, D. S. \& Horstmann, K. (1997): A catalogue of world Ichneumonidae (Hymenoptera). - The American Entomological Institute, Gainesville, 1558 pp.

Yu, D. S., van Achterberg, C. \& Horstmann, K. (2012): Taxapad 2012, Ichneumonoidea 2011. Database on flash-drive. www.taxapad.com, Ottawa, Ontario, Canada.

Received February 26, 2020, accepted May 1, 2020, published August 14, 2020 